\title{
Al-Makīn ibn al-'Amīd on Moses of Crete
}

\author{
Nikolai N. Seleznyov \\ Institute for Oriental and Classical Studies, National Research University \\ Higher School of Economics \\ nikolai.seleznyov@hse.ru
}

\begin{abstract}
In the first, still unpublished, volume of The Blessed Compendium (al-Majmū al-mubärak) - the historical work of the 13th-century Arabic-speaking Christian writer al-Makin ibn al-'Amìd, there is a chapter on the Byzantine Emperor Theodosius II the Younger (r. 402-450). In this chapter, Ibn al-'Amīd retells the famous story of Moses of Crete, "who appeared among the Jews" and declared himself to be the Messiah to subsequent tragic disappointment of those who believed in him. The present article discusses this story and suggests an explanation for the discrepancies between Ibn al-'Amīd's text and its Arabic source - the Book of the Heading (Kitāb al-Unwān) of Agapius of Manbij (Hierapolis).
\end{abstract}

\section{Keywords}

al-Makin ibn al-Amid - The Blessed Compendium - Moses of Crete - Jews - Messiah - Agapius of Manbij (Hierapolis) - Arabic textual criticism

Al-Makīn's ${ }^{1}$ two-volume universal history is arranged as a series of biographies of well-known figures of world history including descriptions of events that took place during their lifetime. The figures are the biblical patriarchs (Seth,

1 See on him: S. Moawad, "Al-Makīn Jirjis ibn al-'Amīd (the Elder)," Christian-Muslim Relations: A Bibliographical History, ed. by D. Thomas [et al.], Leiden, Boston, 2009- (ongoing), vol. 4 (2012), p. 566; M. Diez, "Les antiquités gréco-romaines entre al-Makīn ibn al-'Amīd et ibn Haldūn. Notes pour une histoire de la tradition," Studia graeco-arabica, 3 (2013), pp. 121-140; N. Seleznyov, "The Laments of the Philosophers over Alexander the Great according to The Blessed Compendium of al-Makīn ibn al-'Amīd," Scr, 10 (2014), pp. 97-114. DO I $10.1163 / 18177565-90000093$. 
Enosh, Cainan, etc.), the kings of "the sons of Israel," as well as Babylonian kings (Nebuchadnezzar, Belshazzar), followed by Persian kings (with a special reference to Darius), Alexander the Great and the Ptolemaic dynasty, the Roman rulers, beginning with Augustus Caesar, and the Byzantine emperors. The chapter on Heraclius concludes the first part of The Blessed Compendium. The second part begins with the story of Muhammad and ends, as does the entire history of al-Makinn, with Sultan Baybars' ascent to power (1260).

\section{1 \\ The Chapter on Theodosius II}

The chapter on "the one hundred and fifty-fourth one from Adam, Theodosius the Younger, son of Arcadius" provides an account of the events concerning the controversy between "Cyril, Patriarch of Alexandria" and "Nestorius, Patriarch of Constantinople," followed by the story of Moses of Crete. Subsequently, the teachings of Eutyches and his condemnation are mentioned. There follows a survey of the events which took place in the East with "the kings of Persia" Yazdigerd I and Bahram Gur as well as the "Khaqan of the Turks" during the reign of Theodosius. Al-Makin mentions the flight of Bahram Gur "to the king of India," his elevation there, his marriage to the daughter of the Indian king, and his return with a powerful army. The chapter concludes with a report on the clash between the Jewish and the Christian communities in Alexandria at the time of the "Christian Easter."

In the chapter devoted to Emperor Theodosius II's reign, Ibn al-Amīd retells the famous story of Moses of Crete, "who appeared among the Jews" and declared himself to be the Messiah, intent on gathering the Jews living in Crete and leading them through the separated waters, obviously, to the Promised Land. Here is the story in translation (for a critical edition of the Arabic original, see below):

The Historian said: At that time, a certain man, a Jew named Moses, appeared among the Jews and told them that he had come down from heaven to save them, in the same manner as Moses son of 'Imrān (had saved them from the Pharaoh). This was on one of the islands of the sea, called Crete. One day they walked with him on the seashore, with their children and their wives and a large crowd of them, until they came to a place that 
overlooked the sea. Then he said to them: Verily, I will cross the sea with you (like Moses crossed over with the children of Israel), and many of them rushed into the sea and drowned. When the others saw this, and the fact that he did not save them from drowning, they wanted to seize him. He fled, but they seized him and killed him. And then many of the people became Christians.

The introductory remark "the Historian said" (qālal-mu'arrikh) means that the quotation that follows comes from Agapius of Manbij (Hierapolis), an Arabicspeaking Melkite bishop of the 1oth century, the author of the universal history the Book of the Heading (Kitāb al-'Unwān) ${ }^{2}$. The story of Moses of Crete is indeed found in that book: ${ }^{3}$

At this time, a certain man appeared among the Jews, whose name was Moses, and said to them: Verily, I have come down from heaven to save you, as did Moses the son of 'Imrān. This was on one of the islands of the sea, known as Crete. One day they walked with him on the seashore, with their children and their wives in a large crowd, until they came to a place that overlooked the sea. Then he said to them: Verily, I will take you across the sea, beginning [with myself] ${ }^{4}$. Many of them rushed into the sea and drowned. When the others saw this, and what had happened to their brethren, i.e., that they had drowned, they refrained from throwing themselves [into the water], and wanted to seize him, but he ran away from them, and some unclean spirits accepted him. And [some] people among them became Christians.

\section{$3 \quad$ Socrates Scholasticus and the story of Moses of Crete}

Before focusing on the discrepancies between the accounts of Moses of Crete in Agapius and al-Makīn, it should be mentioned that this story is found as early as in the Church History of Socrates Scholasticus (c. 380 -after 439$){ }^{5}$ It is

2 Kitab al-'Unvan: Histoire universelle écrite par Agapius (Mahboub) de Menbidj, ed. A. Vasiliev (PO 5,4; 7,4; 8,3; 9,1), Paris, 1910-1915.

3 Kitab al-Unvan: Histoire universelle écrite par Agapius (Mahboub) de Menbidj, Seconde partie (II), ed. A. Vasiliev (PO 8,3), Paris, 1912, p. 414/[154].

4 mubtadiyan (standard Arabic: mubtadian).

5 Book VII, chapter 38; Sokrates Kirchengeschichte, ed. G.Ch. Hansen (GCS, N.F., 1), Berlin, 1995, pp. 387-388; English translation: The Ecclesiastical History of Socrates, Surnamed Scholasticus, or the Advocate, Comprising a History of the Church, London, 1874, pp. 378-379. 
also found in Latin historiography, in particular, in the Historia tripartita by Flavius Magnus Aurelius Cassiodorus (c. 485-c. 580), ${ }^{6}$ as well as in the Historia miscella of Landulfus Sagax, which follows the Historia Romana "ad annum Christi 816 " by Paul the Deacon, Warnefridus (c. $720-800) .{ }^{7}$ The story was also known to Syriac historians. For example, it can be found in the Chronicle of Pseudo-Dionysius of Tel-Mahrē $(775 / 6)^{8}$ and in that of Michael the Great (c. 1126-1199). ${ }^{9}$ The story was also retold in the Chronicle of John, Coptic bishop of Nikiu (7th c.), originally written in Greek and, probably, partially in Coptic, but extant in the Ethiopian translation made from Arabic. ${ }^{10}$ We also find the story retold in the Church History of the later Constantinopolitan historian Nicephorus Callistus Xanthopoulos (14th c.). ${ }^{11}$

Latin and Syriac authors, as well as Nicephorus Xanthopoulos, mainly retell Socrates Scholasticus. In the version of John of Nikiu (as far as can be judged from the extant Ethiopian translation) the "disappearance" of Moses of Crete is explained quite simply: that he just drowned (zatasatma). Latin and Syriac authors argue that his "disappearance" has to do with his transformation into an unclean spirit, as is the case in Socrates Scholasticus. Thus, Cassiodorus argues as follows: Cumque voluissent illum perimere seductorem, comprehendere nequiverunt. Repente namque disparuit, deditque suspicionem quia daemon fuerat erroneus, humano schemate circumamictus, ${ }^{12}$ and Michael the Great says: "And when it became known to the rest of the Jews, they rushed from all sides so that they would seize Pseudo-Moses (l-Mūshē daggālā) and did not find him. And they decided that it was a demon who had led them into error."13

6 Magni Aurelii Cassiodori Historia ecclesiastica vocata Tripartita, ex tribus Graecis auctoribus, Sozomeno, Socrate et Theodoreto, per Epiphanium Scholasticum versis excerpta, et in Compendium a se redacta (PL 69), Paris, 1865, col. 1210D-1211B.

$7 \quad$ Historia miscella ab incerto auctore consarcinata, complectens Eutropii Historiam, quam Paulus Diaconus multis additis... et Landulphus Sagax, seu quisquam alius continuavit... (PL 95), Paris, 1861, col. 958C-959B.

Incerti auctoris Chronicon Pseudo-Dionysianum vulgo dictum, ed. J.-B. Chabot (Csco 91, 121, Syr. 3,1-2 [43, 66]), Paris, Louvain, 1927, 1949, vol. 91/[43], pp. 211:12-212:24 (Syriac text); vol. 121/[66], pp. 157-158 (Latin translation). Chronique de Michel le Syrien, patriarche jacobite d'Antioche (1166-1199), ed. J.-B. Chabot, Paris, 1901, vol. 4, p. 178 (Syriac text); vol. 2, pp. 25-26 (French translation).

10 Chronique de Jean, évêque de Nikiou, ed. H. Zotenberg, Paris, 1883, pp. 117-118 (Ge'ez text), 347-348 (French translation).

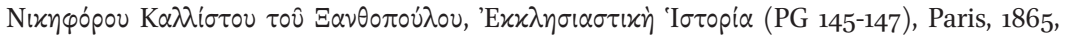
vol. 146, col. 1199-1202. I am grateful to A.V. Simonov for this reference. Chronique de Michel le Syrien, p. 178 (Syriac text), 26 (French translation). 
It is in the account of the demise of the hapless Cretan Messiah that we find the main difference between Agapius' and al-Makin's texts. Moreover, the edition of Agapius (as far as can be judged from the edition of Alexandre Vasiliev) has significant discrepancies as compared to the text of Socrates Scholasticus. The corresponding fragments of these three accounts can be presented synoptically in the form of a table:

\begin{tabular}{|c|c|c|}
\hline Socrates Scholasticus ${ }^{\mathrm{a}}$ & Agapius of Manbij ${ }^{b}$ & al-Makīn ibn al-Amīd \\
\hline $\begin{array}{l}\text { When at length the Jews } \\
\text { perceived how fearfully they } \\
\text { had been duped, they blamed } \\
\text { first of all their own indis- } \\
\text { creet credulity, and then } \\
\text { sought to lay hold of the } \\
\text { pseudo-Moses in order to put } \\
\text { him to death. But they were } \\
\text { unable to seize him, for he } \\
\text { suddenly disappeared: which } \\
\text { induced a general belief that } \\
\text { it was some malignant fiend, } \\
\text { who had assumed a human } \\
\text { form for the destruction of } \\
\text { their nation in that place. }\end{array}$ & $\begin{array}{l}\text { When the others saw this, } \\
\text { and what had happened to } \\
\text { their brethren, i.e., that they } \\
\text { had drowned, they refrained } \\
\text { from throwing themselves } \\
\text { [into the water], and wanted } \\
\text { to seize him, but he ran away } \\
\text { from them, and some unclean } \\
\text { spirits accepted him (الارواح النجسة. }\end{array}$ & $\begin{array}{l}\text { When the others saw } \\
\text { this, and the fact that } \\
\text { he did not save them } \\
\text { from drowning, they } \\
\text { wanted to seize him. } \\
\text { He fled, but they seized } \\
\text { him and killed him } \\
\text { (فلحقوه وقلوه). }\end{array}$ \\
\hline
\end{tabular}

a The Ecclesiastical History of Socrates, p. 379.

b Kitab al-Unvan: Histoire universelle écrite par Agapius (Mahboub) de Menbidj, Seconde partie (II), ed. A. Vasiliev (PO 8,3), Paris, 1912, p. 414/[154].

The cause of the discrepancies between the narratives of Agapius and al-Makīn can be found by examining the Arabic texts. Ibn al-'Amīd probably used a copy of the Book of the Heading of rather poor quality, and even if the words that Pseudo-Moses was "accepted by some unclean spirits" were discernible in the copy, they could have hardly seemed to him to be intelligible because this construction is not used to refer to a "possession" by a demon. It is more likely, however, that the text was corrupt (as evidenced by the corruption of "to their brethren" - li-așhābihim - into "does not save them" - la yanjīhum), and the words "accepted him" (qabilūh) and "killed him" (qatalūh) might be indistinguishable in Arabic writing with fuzzy or absent diacritics, which is not 
uncommon in medieval Arabic manuscripts. After linking the verb "killed" with "others" (Jews), al-Makin no longer needed "unclean spirits" as the subject, if these words were readable in the copy of the Book of the Heading he used.

It is worth mentioning that Elias of Nisibis, Metropolitan of the Church of the East (975-1046), wrote in the sixth majlis of his Book of Sessions, containing a comparative analysis of the grammar and other philological issues among the Arabs and the Syrians, that in Arabic writings -

Due to the similarity of letters, in the correspondence, there happened confusions, the number of which exceeds any description, when, for example, it was said instead of "Get away from us" "Anoint themselves sometimes,"14 and instead of "Accept the people" - "Kill the people" (اقبلوا (القوم باقتلوا القوم , and numerous similar [examples].15

Was Agapius a victim of a similar damage to the manuscript of the History of Socrates Scholasticus, which he used, as a result of which the "demon who assumed a human form" transformed under his pen into "acceptance" by the demons of Pseudo-Moses? Or was this transformation a result of the copying of the Book of the Heading by one of the later scribes? The investigation of these issues would be interesting, but it is beyond the scope of the present study.

$\mathrm{P}$ - Paris, Bibliothèque nationale de France, ar. 294 ${ }^{16}$, fol. 229:6-14.

V - Vatican, Biblioteca Apostolica Vaticana, ar. 168², fol. 184r:5-15/p. 368.

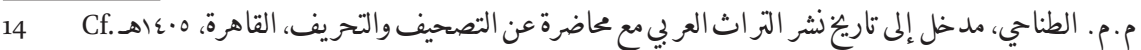

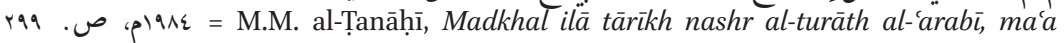
muhạdara 'an al-tașhîf wa-l-tahrî́f [Introduction to the history of the publication of the Arabic heritage with a lecture on misreading and distortion], Cairo, 1405H/1984, p. raq.

كَاب المجالس لمار إليا مطران نصيبين و رسالته إلى الو زير الكامـل أبي القاسه الحسين بن على المغربى، تحقيق Kitāb al-majālis li-Mār Iliyyā, muțrān Nușaybìn, warisālatuhu ilā l-wazìr al-kāmil Abì l-Qāsim al-Husayn ibn 'Alī al-Maghribī, taḥīi Nīkūlāy Sīlīznyūf [Book of Sessions by Mār Elias (Iliyyā), Metropolitan of Nisibis, and his Epistle to the Perfect Vizier Abū l-Qāsim al-Ḥusayn ibn 'Alī al-Maghribī, ed. N. Seleznyov], Moscow, $1439 \mathrm{H} / 2017 / 8$, p. «).

16 G. Troupeau, Catalogue des manuscrits arabes, Paris, 1972, part 1, vol. 1, p. 261.

17 A. Mai, Scriptorum veterum nova collection e Vaticanis codicibus edita, Rome, 1831, vol. 4, pp. 308-309. 
$\tilde{V}$ - Vatican, Biblioteca Apostolica Vaticana, ar. 169 ${ }^{18}$, fol. 164V:10-16.

M - Munich, Bayerische Staatsbibliothek, ar. 3769 , pp. 247:38-248:7.

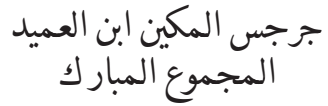

(fragment)

قال المؤرخ:20 وفي ذلك الزمان ظهر بين اليهود رجل يهودي221 اسمه موسى فقال لهم 22 انّه نزل

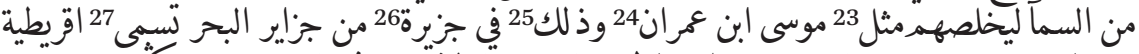

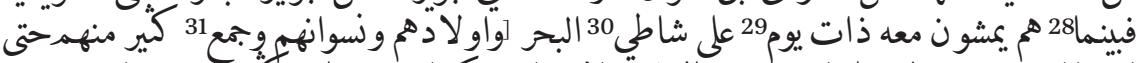

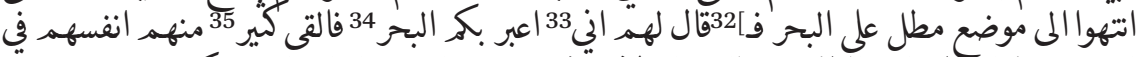

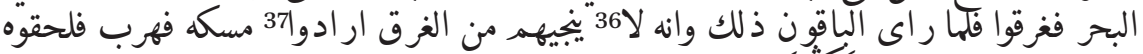

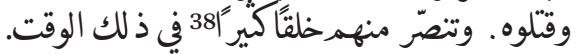

18 A. Mai, Scriptorum veterum nova collection e Vaticanis codicibus edita, Rome, 1831, vol. 4, pp. 308-309.

19 J. Aumer, Die Arabischen Handschriften der K. Hof-und Staatsbibliothek in Muenchen, Munich, 1866 [reprint: Wiesbaden, 1970], pp. 140-141.

20 P abs.

21 رجلاً يهودي

$22 \tilde{\mathrm{V}} a b s$.

23 MVṼ خصك

24 MVṼ add.

25 وكان ذلك

26 جزيرةً 25

27 P abs.

28 MVṼ

29 Vو ل

30 ساحل

31 وجميع Ms 30

32 وجميع وجن

33 M L ا

34 MVṼ add. كماعبر موسى ابن عمران ببني اسرايل

35 V 35

$36 \quad \mathrm{P}$ ।

37 اراد

خلق كيّر M 